\title{
Animals, Capital and Sustainability
}

\author{
Thomas Dietz \\ Environmental Science and Policy Program, \\ Department of Sociology and Animal Studies Program, \\ Michigan State University, East Lansing, United States \\ Richard York \\ Department of Sociology and Environmental Studies Program, \\ University of Oregon, Eugene, United States
}

\section{Abstract}

Taking serious consideration of the engagement of non-animals in human-society often transforms our understanding of human society. Here we offer insights that come from considering the role of non-human animals in the production of human well-being. Drawing on Braverman's critique of the deskilling of labor, we examine the effects of the drive for efficiency in capitalist production on both humans and non-human animals. Non-human animals provide well-being through their role in ecosystem services, as companions, as objects used as both raw materials and as processors of raw materials, and as labor. The drive for efficiency impacts all four of these roles, especially by reducing the agency of non-human animals. Our analysis suggests several lines for future research, and re-enforces the idea that taking non-human animals seriously can substantially hone thinking in human ecology.

Keywords: deskilling of labor, animal labor, efficiency, agency

\section{Introduction}

Recent scholarship in the area of Animals and Society has "brought animals in" to social science discourse by making it clear that non-human animal species are active, engaged and integral parts of human society, and of coupled human and natural systems. This work has shown that our understandings of agriculture (Gunderson, 2013), identity (Jerolmak, 2013), technology (York \& Mancus, 2013) and violence (Fitzgerald, Kalof, \& Dietz, 2009), among many other topics, shift when we take non-human animals seriously (for additional examples,

$1 \quad$ Author contact: tdietz@msu.edu. 
see York, 2014). This literature challenges us to more fully integrate non-human animals into human ecology and recognize that animals are more than symbols or social constructions (York \& Longo, forthcoming).

In this essay, we offer some thoughts about one approach to bringing nonhuman animals into discussions of human ecology and sustainability theory. We do not suggest the approach we outline here is the single or the best way to incorporate animals into human ecology, but that it is one useful way to engage existing theories about economic and social development and sustainability. We will not take up the complex ethical issues involved in considering humananimal relationships, but we consider these highly important and necessary for developing any program for social change. Rather, we will develop arguments around the production of human well-being and the several ways in which nonhuman animals contribute to human well-being. In particular, we will argue that taking animals seriously encourages us to think in new ways about the production function for well-being. ${ }^{2}$

The basic framework of the production function is based on the recognition that humans deploy resources to produce goods and services that enhance their well-being. While the idea of the production function was initially developed to understand how industrial firms operated, the concept was quickly expanded to explain the economic output of nations and, ultimately, the livelihood activities of households (Dietz, 2015). While this might seem an esoteric topic, the logic of the production function is fundamental to much thinking about sustainability. The most common definition of sustainability is usually traced to the Brundtland Report, where sustainable development is defined as a process of development that "meets the needs of current generations without compromising the ability of future generation to meet their own needs" (World Commission on Environment and Development, 1987, p. 23). Meeting the needs of current and future generations requires the production of goods and services. So sustainability theory is essentially asking questions about how current actions will affect the ability of future generations to produce wellbeing. That question can be made precise by thinking about what is necessary to produce well-being: the production function.

In the classical formulation of the production function, societies or firms deploy three kinds of resources: manufactured resources (tools, equipment, physical infrastructure, etc.), land and labor. In modern terminology, we refer to natural resources rather than land. Sometimes the term human resources is used instead of labor but if we look across the scope of human history, animals have also been an important source of labor. One of the most important debates in sustainability theory - strong versus weak sustainability - is about the degree to which one

2 Of course, humans are animals. But to simplify writing, from this point on in the essay we will typically use the term "animals" to refer to non-human animals. 
kind of resource can be substituted for another (Neumayer, 2010). Advocates of weak sustainability argue that it is often feasible to substitute one type of resource for another in the production of well-being. Thus, it might be prudent to deplete natural resources to build up the stock of manufactured resources and human resources for future generations. Advocates of strong sustainability argue that substitution across types of resources is limited and so our obligation to future generations is to provide adequate supplies of all three resource types.

The production function logic also appears in major assessments and policy analyses as well as in the research literature. The central theme of the Millennium Ecosystem Assessment (MEA) is the contribution of ecosystem services to the production of human well-being (Reid et al., 2005; Yang, Dietz, Kramer, Chen, \& Liu, 2013; Yang, Dietz, Kramer, Ouyang, \& Liu, 2015; Yang, Dietz, Liu, Luo, \& Liu, 2013). The relative efficiency of nations, other geopolitical units, communities and even households in producing well-being underlies the literature on Environmental Intensity of Well-Being (EIWB) (Dietz, Rosa, \& York, 2009; Jorgenson, 2014; Jorgenson \& Dietz, 2015; Lamb et al., 2014; Mazur \& Rosa, 1974; Mulder, Costanza, \& Erickson, 2005; Steinberger, Roberts, Peters, \& Baiocchi, 2012; Vemuri \& Costanza, 2006). We believe that by examining how non-human animals participate in the production of human well-being, we can clarify how that process actually takes place and highlight the political struggles around it.

Our work has strong parallels to Gunderson's arguments about the negation of animal needs under the logic of capitalist production, especially his insight, drawn from Adorno (1966), that the domination of nature required for capitalist production is violent (Gunderson, 2013). ${ }^{3}$ Our arguments are similar to those of Hribal on animals and agency and the resistance of animals to the labor process (Hribal, 2003, 2007). York and Mancus's examination of the role of nonhuman animals in the historical trajectory of human societies is a foundational underpinning of our thinking (York \& Mancus, 2013). But while these efforts inform our work, our goal is somewhat different. We want to explore the implications of thinking seriously about animals for the kinds of production processes that are at the heart of sustainability theory.

We will begin with an examination of the production of human well-being and the drive for efficiency per unit labor in capitalist production. We then suggest four ways in which non-human animals contribute to the production

\footnotetext{
3 Use of violence as a means to control the production of raw materials and goods, and access to markets and trade has been a key feature of capitalism (Beckert, 2014; Lough, 1999). So, in a sense, the logic of violence against animals fits with the historical development of capitalism. This is not to argue that other ways of organizing production have not involved violence. Evidence about the amount of violence in food foraging societies is debated (Boehm, 2012; Bowles, 2012; Fry, 2012; Lawler, 2012a; Lawler, 2012b). But at least since the rise of horticulture and certainly with the rise of states dominated by elites, violence has been a tragically common part of the production process, including both organized warfare to appropriate control of resources and violence in the control of human and animal labor.
} 
of well-being and how the drive for efficiency effects each. We conclude with some suggestions regarding the implications of bringing animals into the logic of production of well-being and suggest some questions for further research.

\section{Efficiency in production}

\section{The production of human well-being}

In its early use the production function was conceptualized around the output of goods from factories, but this was quickly generalized to the overall output of goods and services in a society. In parallel, the output of goods and services came to be equated with utility - the satisfaction produced from goods and services - which is a form of subjective well-being. Thus, the output of the production function was assumed to be equivalent to human well-being. ${ }^{4}$

The basic idea of the production function is that households, firms, communities or nations make use of the resources to which they have access to produce wellbeing. In many analyses, national well-being is equated with economic output of the sort measured in standard national accounts, such as gross domestic product per capita. For households or firms the desired outcome is measured in income or profits. Efficiency can then be defined as how much output is produced per unit of input.

This formulation - that human well-being is served by deploying manufactured, natural and human resources in production - has long been the basis of policy (Dietz, 2015). The equation of well-being with economic output implies that growth in output, that is growth in profits for firms, gross domestic product per capita for nations and income for households, is socially beneficial. This logic

4 The founders of utilitarianism often argued for considering the well-being of non-humans, and utilitarianism continues to provide an important basis for arguments about animal rights and the treatment of animals (Frey, 2011). But the versions of utilitarianism that have influenced contemporary economics do not take into account the well-being of non-humans except as it effects human well-being. 
underpins the politics of the treadmill of production or growth machine that has dominated economic policy in the developed nations at least since World War II (Logan \& Molotch, 1987; Schnaiberg, 1980). ${ }^{5}$

While the logic of the production function can be applied to all societies, a key feature of capitalist economies is production for profit. This is what differentiates the idea of capital from the idea of a resource. A resource may be deployed to produce well-being. But under capitalism, the principal goal in using resources is to produce profit. Resources are used as capital to produce outputs that have greater market value than the inputs. As Bourdieu puts it, capital has "potential capacity to produce profits and to reproduce itself in identical or expanded form" (Bourdieu, 2008, p. 280). To use classical Marxist terminology, in capitalist economies, the goal is to produce exchange value rather than use value and to have the scale of exchange value continually expanding. ${ }^{6}$

This leads to the question that underpins our analysis: how do those seeking profit from their use of resources manage the production process to produce profit, and what are the implications of these strategies for animals? Braverman's insightful analysis of the labor process makes clear the conflict between those who are managing the labor process - capitalists and their agents - and the human resources they deploy in the process-workers (Braverman, 1974). We believe his argument also provides insights into the situation of animals in contemporary capitalist production. We begin by sketching his arguments and then turn to its application to animals.

\footnotetext{
5 The critique of growth for growth's sake is a central tenant of many analyses of environmental and sustainability issues. We endorse this critique, but we also note that there are many people at present who suffer from material deprivation and would benefit from increased consumption. However, providing more to the poorest people does not require an increase in aggregate consumption - indeed it could be accomplished with a substantial decrease in aggregate consumption - since consumption is very unequally distributed, so that a decline in consumption by the most affluent people in the world would allow for more consumption by the poorest without overall growth. During the historical period when the production function and theoretical interest in growth developed, even the most affluent nations had modest economic output by today's standards. For example, the GDP per capita of England grew from around US\$1,540 (in 2005 dollars) in 1700 to approximately US\$2,200 in 1800 (Bolt \& van Zanden, 2013). In comparison, Egypt's 2013 GDP per capita was US\$1,566 and Morocco's was around US\$2,500 (both in 2005 dollars). But, of course, even at low levels of affluence growth improves overall well-being if and only if the benefits of growth reach those who are most disadvantaged, which too often is not the case.

6 Of course, much of welfare economics would argue that increased production of exchange values in a market economy will enhance the ability of the population to consume desired goods and services, potentially including leisure and the appreciation of nature and culture, and thus enhance well-being. The relationship between this hypothetical situation in theoretical welfare economics and the processes unfolding in the contemporary world is a critically important topic that is beyond our scope here.
} 


\section{The drive for efficiency}

In standard economic analysis, the cost of labor is assumed to be determined by the market for labor. Thus capitalists should structure the labor process so that as much output is produced per unit labor cost as possible. In theory, capitalists and managers cannot directly influence the price of a unit of labor, only how many units of labor they need to produce a given amount of output. ${ }^{7}$ They will attempt to increase the efficiency with which labor inputs lead to output. Indeed, output per unit labor is so central to production and the pursuit of profit and growth that in many economic discussions, the term efficiency, used without modifier, means output per unit labor ("labor productivity") rather than output per unit manufactured or natural resource.

Braverman's core argument is that efforts to increase the efficiency of the production process - to rationalize it-involve the deskilling of labor by embedding the skill of workers in routines and in machinery (manufactured resources). This has two advantages for those organizing the production process. First, deskilling and rationalization can increase the output per unit of labor input. For humans, this came first with Taylorism, in which studies of what workers did in the production process was used to simplify tasks and make workers more interchangeable. This rationalization may lead to more effective ways of carrying out the actions of production via best practices. But it also increases control over labor, which can make workers more efficient at producing output in part because they are more easily subject to monitoring and control and are less able to take any actions at work other than those that serve production. Of course, rationalization also can lead to less time-consuming ways of doing things - the way we usually think about increased efficiency.

Second, deskilling what is needed from labor in production greatly weakens the bargaining power of human workers. If workers possess special skills that are hard to acquire, their bargaining position for a share of profits is bolstered by their ability to disrupt the production process by slow-downs, walk-offs, strikes and simply by finding employment elsewhere. But if they are easily replaceable because a new worker can acquire the needed skills very quickly, human workers lose bargaining power and the owners of capital can appropriate a larger share of profits.

From the start, part of the deskilling of labor was to embed more and more complex activities in manufactured resources. This process began during the Industrial Revolution when the skills of craftspeople, such as weavers, were

7 In practice, one major strategy, ironic in a system whose logic is often justified by the effects of competition, is to eliminate or minimize competition by creating oligopolies, oligopsonies, monopolies and monopsonies that allow strong influence on the prices of inputs and outputs rather than accepting market prices. 
roughly replicated by machines, notably mechanical looms (Beckert, 2014). It continued in the 20th century with automation and the first industrial robots, and continues to expand as increased capabilities of robots and artificial intelligence displace more and more human skills. Historically, manufactured resources possess no agency. Thus using manufactured resources enhances efficiency via the first strategy - machines do what they are programmed to do. While there may be errors in design that lead a machine or a production system to behave in ways that are not anticipated, it is difficult to argue that manufactured resources follow their own agenda (Latour's efforts to expand the concept of agency aside (Latour, 2014a, 2014b)). This may change as we use increasingly complex and powerful artificial intelligences and robots that might be viewed as possessing some degree of agency (Barrat, 2013). ${ }^{8}$ But for the moment, manufactured resources are free of agency that could reduce the ability of their owner to control the production process. So moving skill from human resources to manufactured resources increases control over the production process. There is an equally long history of using machines to displace animals in order to increase efficiency and control. We will discuss this in the next section of the paper.

\section{Bringing animals back in}

Having laid out an analysis of the production process, we now turn to how animals contribute to human well-being. For our purposes, it will suffice to distinguish four types of animal contribution: as key components of all of the ecosystems upon which humans depend for survival; as companions; as objects that can sometimes be treated simply as natural resources and at other times rather like manufactured resources; and as labor. As we will see, the boundary between these categories is fluid. The contributions of some species to human well-being might fall primarily into one category. But in general it is an interaction between the evolved (and especially co-evolved) characteristics of a non-human species and a particular form of human engagement with that species that defines how a particular non-human animal contributes to human well-being at a particular time and place.

\section{Animals as part of ecosystems}

As the MEA documented, humans depend on ecosystems for survival and the production of well-being in myriad ways. These include direct use through activities such as agriculture and forestry. They also include less direct benefits

8 Ethical obligations towards artificial intelligences and robots is a serious topic of discussion in the community doing research on these systems, addressing questions that go back at least to Isaac Asimov's contemplations on robots in human society; see especially his discussion of whether or not the term "killed" can apply to a robot in The Robots of Dawn (Asimov, 1956, 1983) 
from ecosystems, including the simple aesthetic appreciation of them, as well as ecosystem processes that regulate climate, water supply, production of soil and much else critical to human well-being (Reid et al., 2005). Animals influence all other components of ecosystems, such as plants and fungi, and thus directly and indirectly influence ecosystem structure and function and biogeochemical processes. For example, worms and nematodes are central to building the fertility of the soil on which humans depend for food and fiber production, and the manure from large mammals is an important source of nutrients for soil. But the importance of animals as part of ecosystems goes well beyond simple and direct contributions such as these, since they are intimately tied in the web of interactions among living and non-living components that make ecosystems function. Without ecosystem services human societies could not survive, and without animals the ecosystems of the world and the biosphere itself would not be remotely like it is. As animal populations change, often as a result of human intervention, the ecosystems and the services humans can derive from them also change with attendant impacts on human well-being.

The effects of production processes on ecosystems are of course a central theme of ecology, human ecology and environmental science. Using ecosystems as a source of raw materials and as a sink for waste changes their structure and function. The MEA estimates that $60 \%$ of the types of ecosystem services examined are being degraded or used unsustainably (Reid et al., 2005). More recent assessments reach similar conclusions - human activity is substantially altering the structure and function of ecosystems around the planet with problematic implications for the well-being of both humans and other species (Hughes, Carpenter, Rockström, Scheffer, \& Walker, 2013).

\section{Animals as companions}

Engagement with species that have co-evolved to interact socially with humans is a major source of well-being for many people. In the case of dogs, Homo sapiens and Canis familiaris have been domesticating one another for at least 12,000 and perhaps more than 32,000 years (Grimm, 2015; Shipman, 2015). The result is a close and satisfying emotional bond (MacLean \& Hare, 2015; Nagasawa et al., 2015). The period of co-domestication has been shorter for other species, but there are many domestic and even liminal species that interact with people in mutually satisfying ways (Clutton-Brock, 2012; O'Connor, 2013).

Of course, the evolution of mutualistic interactions between humans and other animals has often been related to production. Dogs aid in hunting and in guarding their human group and other domesticated animals. Cats prey on mice and other species that consume human food supplies. Birds have been trained for hunting. Horses have been a major source of labor for transportation and agriculture. Indeed, the distinction between horticulture and agriculture in 
many areas of the world is defined in part by the use of equids for labor (York \& Mancus, 2013). But while animals still fulfill these roles in production in many parts of the developing world, in the developed world most of the benefit from these species is simply from social interaction with them.

In some cases, humans derive substantial satisfaction from observing or even simply contemplating other species without direct interaction. The obvious example is the many species that are classified as wildlife, especially birds and large mammals. Overall, the value to human well-being from interaction with animals and the benefits to humans derived from their existence have been recognized by the MEA as "cultural services" (Reid et al., 2005). The MEA acknowledges that very substantial and important cultural services flow from both human-dominated and relatively pristine ecosystems.

While we are not aware of research on this issue, it may be that contributions to human well-being of animals as companions and objects of contemplation requires that we view those animals as having agency. Although we may become frustrated with some actions of domesticated species, we certainly expect our companion animals to act with some degree of autonomy and even emotional engagement. It may also be that the contemplation of wildlife is in part derived from thinking of those animals - ungulates, large predators, marine mammals, birds and many others - as independent organisms who act as authors of their own lives. ${ }^{9}$ If that is the case, then we would expect less success at rationalizing the production of this form of well-being. However, we note that commercial enterprises, whether the production of nature documentaries or marine theme parks, do seem to move towards increased efficiency in the production of engagement with other species. And certainly the pet breeding industry has developed conditions, such as puppy mills, for producing dogs, cats and other species of companion animals at low economic cost although often with great cruelty.

\section{Animals as objects}

Animals are also treated as natural resources, and enter into the production of human well-being as a material input, much as a mineral or plant might. In addition, animals, with the ability to produce meat, milk, eggs, fur, wool and other valued materials often play much the same role as some kinds of machines - they transform inputs into more useful outputs. We aggregate both these roles in production into the general category of animals as objects. As both Gunderson and Hribal have shown, an industrial capitalist political economy

9 This creates a special ethical dilemma. There is a long tradition of displaying the animals we consider most interesting in zoos. But if our conjecture is correct and we are most interested in and most enjoy seeing animals that are capable of an autonomous life with agency, then we are confining those species that will suffer most to the limited space and possibility for activity of zoos. 
favors organization of production so that all inputs, including animals, can be treated as acting in predictable ways and controlled so as to increase efficiency. We will discuss three forms of the use of animals as objects: as individuals pursued by hunters; as natural resources to be harvested; and as living "processors" that transform input materials into desired output materials. Each of these is somewhat distinct but for ease of explication we have included all three in the general category of "objects."

Many accounts of hunting describe an extensive interaction between hunters and the animals they hunt. Certainly, in cultures where hunting provides a substantial portion of food it seems to be common to treat the hunted animals as individuals with agency who deserve respect and even gratitude. ${ }^{10}$ But in large-scale commercial hunting, such as 19th-century buffalo hunting in western North America, the use of "punt guns" for massive killing of game birds, industrialized whaling and much of contemporary commercial fishing, animals are clearly natural resources to be harvested-they are objects. If animals are inputs to a production process, then there will be pressure to reduce the agency of the animal so as to be able to treat it as an interchangeable and predictable object, whether the animal is raised in agriculture or hunted in the wild. ${ }^{11}$ This is very evident in the evolution of commercial fishing (Longo, Clausen, \& Clark, 2015).

Hunting remains culturally important in some socities, and in some places and for some people is economically important. Harvesting of non-domesticated animals, especially of fish, is also highly significant in some communities and for some countries. But the major contemporary human use of animals as objects is in agriculture. It is still useful to make a distinction between animals we hunt and animals that are domesticated, but we acknowledge that distinction has always been and continues to be blurred. The logic of making the distinction is that hunted animals are under only modest human control and so most efforts to increase efficiency come in the form of the technology, including social organization, of harvesting.

By contrast, in agriculture the full process of production is managed to increase efficiency, and animals are treated rather like machines for transforming inputs into valued outputs. Production processes that use animals in this way include, inter alia, fish farming, feedlots for production of beef, battery cage operations

10 This is not to deny that mass harvesting of animals seems to have been a part of many human cultures. While the role of human hunting in the extinction of Pleistocene megafauna continues to be debated, it is clear that many human societies have at least sometimes deployed hunting methods that in some ways resemble the mass harvesting that occurs under capitalist production.

11 Even trophy hunting, where the claims of hunters nearly always involve engagement with an animal that exhibits considerable agency, seems to move towards rationalization, with "canned" hunts in which the guides and firms being paid to structure the hunt go to great lengths to make sure that the right kinds of animals will be readily accessible to the hunters paying for the experience (Ireland, 2002). 
for the production of eggs and confinement of sows. The search for efficiency leads to carefully researched regimens of food, supplements and medications to maximize production per unit input. And here too, the agency of the animal to do anything except produce the intended product is sharply restricted, typically with highly crowded conditions and limitations on the ability of the animal to pursue its own intentions, to interact with conspecifics and even to move. These conditions are well documented; we are simply noting that this is one more example in which the drive for economic efficiency in the production of outputs desired by humans leads to restrictions on animal agency and often to violence and cruelty.

\section{Animals as workers}

The fourth role in which animals contribute to human well-being is as workers. Throughout most of human history, animals have had a special role in the production of goods and services, acting as a form of labor that complements the labor of humans. We want to interrogate that role and its contribution to production, and to consider how the role of animals focuses attention on some general processes in the evolution of production in a capitalist political economy.

Thinking about agency and skills in production has usually considered only human resources. But non-human animals possess agency and in some cases skills that can contribute to the production process. In pre-industrial capitalist production systems, this agency could be deployed to good effect at least some of the time. Many domesticated animals act in ways that facilitate their use to produce human well-being precisely because humans and these animals have coevolved in ways that might be considered mutually beneficial. Horses can follow routine paths with minimal direction, sheep and cows can be readily herded, cows want to be milked, cats are autonomous hunters of mice, and dogs in particular interact with humans more as partners than as automatons. Of course, anyone who has worked with any domestic animal will know that animal agency is not always at the service of the production of human well-being. Animals act in idiosyncratic ways that occasionally can be dangerous, vexing and somewhat inefficient when they are viewed as a resource used for production. Thus the history of human interactions with domestic animals involved the invention and refinement of methods to exert control over the agency of domesticssometimes gently, sometimes cruelly (Clutton-Brock, 2012). Hribal (2003, 2007, 2010) elucidates the many forms of resistance that animals have offered as well as the many forms of control humans have exerted over them.

Unlike human workers, animals who are part of the production process cannot organize to represent their own interests. They cannot bargain for a larger share of profits, so they are not a threat to efficiency per unit labor cost in the way organized human workers can be. But, animals can behave idiosyncratically and 
in that way reduce control over, and thus the efficiency of, production. Thus, a key dynamic of animal agriculture since World War II is increasing reduction in the ability of animals to act with agency and behave idiosyncratically. Just as the dynamic of ever-increasing efficiency leads to making the tasks of the human worker more routinized, predictable and controlled by management, so the tasks of non-human animals engaged in the production process become more uniform and more tightly controlled. Animals are treated more like machines or raw materials with predictable characteristics for the production of biological products than as independent organisms with distinct characteristics(Boyd, 2001; Gunderson, 2013; Hart \& Mayda, 1998; King, 2000; MacDonald \& McBride, 2009). That is, animals have moved from being more or less like human labor in the production function to being more like manufactured or natural resources; the same process Braverman has documented for human workers. The tendency has been to convert animals used as labor into animals used as objects that transform raw materials into desired products.

\section{Implications of animals in the production function}

Our basic argument is that resources become capital when they are organized to produce profit and growth. We then note that some types of resources-humans and many non-human animals - actively resist control by those organizing the production process. Thus to increase the efficiency of the production process, those seeking to use resources as capital have to find a way to either reduce their need for resources with agency or to reduce the resources' agency. We believe that this has a number of implications for human ecology and for sustainability theory.

Resources become capital through the exercise of power. Which resources can be treated as capital and controlled by managers and owners, and which remain as labor acting with agency, is not an inherent feature of the resource; rather, it depends on the social and technological organization of the production process. The use of a resource as capital often emerges from an interaction between the features of the resources and the social rules in play - norms and institutionsin a particular time and place. For too much of human history, humans were treated purely as capital in a production process via the institution of slavery. But of course the history of slavery is also a history of resistance, revolt and efforts to bring about abolition. Concerns with the treatment of non-human animals were often linked to efforts to end slavery (Hribal, 2003, 2007). There were also independent moves to protect animals, with the first laws against cruelty toward animals enacted in Ireland in 1635 (Kalof, 2007). 
But there is of course a major difference between human and non-human animal resources. While some humans struggle on behalf of both humans and nonhumans who are ill-treated, and both humans and non-humans have some capacity to directly resist efforts to control them, non-humans do not organize slow-downs, walk-outs, strikes or political movements, nor can they quit to seek "employment" elsewhere. Animals may resist control but they do not organize collective actions with demands for change. They are dependent on social movements and changes in moral norms in human societies to advance their interests. But the larger point remains: the production function is shaped not just by technology and scientific principles but also by laws, norms and institutional arrangements, especially those affecting the ability to shape the behavior of those in production who can exercise agency. Schnaiberg (1980) and neo-classical environmental economists have shown that profits can be increased by ignoring the environmental costs of production. So too profits can often be increased by reducing the agency of humans and non-human animals in production and ignoring the loss of well-being for some humans and animals that results.

Non-human animals complicate the logic of the production function. The agentic nature of at least some animal participation in production suggests a supplemental dimension exists beyond the simple tripartite distinction of manufactured, human and natural resources. We can ask the degree to which a resource can exert agency of either the first (organizing) or second (disruption of routine) type. The answer to this question is not entirely determined by the nature of the resources; it also depends on the political organization of the production process. Some humans - highly skilled workers organized into powerful unions - can exert substantial agency. Sometimes that agency is a drag on efficiency in the traditional sense of output per unit labor, although those inefficiencies may result from changes in the production process that enhance human well-being beyond what more efficient output would yield. While the labor costs of some goods or services may increase, making the goods more expensive, this might be the result of changes in working conditions and incomes that overall enhance well-being more than the increase in prices degrades it. In other cases - such as with low-skill workers with no political power drawn from a large labor pool - the ability to organize is minimal. But even when workers lack political power, they still have varying degrees of ability to act idiosyncratically-much depends on the technology to monitor their actions.

Most natural resources - e.g., minerals - have no agency. But animals are an exception. Indeed, where animals fit in the tripartite division of manufactured, natural and human resources is problematic. As we have argued, most contemporary processes that pursue "wild" animals as game attempt to treat 
them as natural resources in the traditional sense-inputs with no agency. The same is true of domesticated animals where the general trend in animal agriculture has been to reduce any agency on the part of animals.

Before agriculture was mechanized, animals used as labor have been a key part of the production process and such labor is still important in the developing world. But since the Industrial Revolution most animals used to provide power in the form of plowing, pulling loads, turning winches and so on have been replaced by machinery, and in the last 150 years that machinery is driven largely by fossil fuels. Of course there are substantial engineering advantages to using a machine rather than an animal as a source of mechanical power. But there is also an increase in efficiency based on the removal of animal agency from the production process.

Since the middle of the 20th century, great effort has been made to increase the efficiency with which animals used as objects produce meat, eggs and dairy products. This has been the result of selective breeding for genomes better suited to human needs, use of feed supplements and antibiotics, and the design of technologies such as the feedlot, the battery cage and the gestation crate, that maximize the output per animal by decreasing any freedom or agency the animal has to engage in activities that would reduce production of the desired product. In parallel to Braverman's analysis of the rationalization of human labor, the production of meat, eggs and milk has been designed to ensure that the animals engage only in those activities that maximize output and thus profit. Now, experiments are underway for the in vitro production of foodstuffs including "animal" protein. As Gunderson notes, in the long run, this may change the conditions of animals in agriculture, reducing the need to treat animals as machines or raw materials (Gunderson, 2013).

\section{Coda}

Our major point is that ignoring the role of animals in production processes likely misrepresents those processes. In contrast, thinking about non-human animals as well as humans as resources for the production of goods and services raises at least two important issues that, while not invisible from other perspectives, at least are less sharp. The first of these is that agency can be a source of resistance to the rationalization of production in two ways. On the one hand, humans may actively organize to represent their interest and demand both changes in the production process and an increased share of profits. On the other, both humans and many non-human animals also exert agency by behaving in ways that are not fully predictable and thus interfere with strategies to get them to 
behave more like machinery. While the same strategies are sometimes effective at minimizing both forms of agency, and while the two forms are not wholly distinct, we feel it is nonetheless useful to consider both.

Second, we have noted that monitoring, controlling and standardizing the actions of humans and other animals is important in improving efficiency and profits. While such efforts may increase output per unit of human and animal resource used in production, this should not be conflated with an increase in the wellbeing of humans and other animals for at least two reasons. First, this process reduces the ability of human workers to bargain for a share of profits and thus may exacerbate inequality. Second, both human workers and animals often suffer in small and large ways, from boredom and alienation to experiencing injury, pain and even death as a result of the drive for efficiency. Gunderson makes this point about the cruelty involved in the rationalization of animal agriculture (Gunderson, 2013). So while an increased availability of goods and services may contribute to enhanced human well-being, at least in some circumstances, the increased suffering that may accompany increased productivity reduces well-being. This suggests new questions for the Environmental Intensity of Well-Being research program: Does decreased use of animals as a form of labor increase human well-being? Does increased use of animals as a "raw material" (natural resource) lacking agency increase human well-being? Is there a way to take account of the well-being of non-human species in the EIWB program?

These remarks are only an initial foray into these issues. Our arguments may be flawed in detail and we have certainly not done justice to the existing literature. But we hope that they make clear that structural human ecology and sustainability theory, as they evolve, should take "the animal question" seriously. It is important in its own right on both scientific and ethical grounds. And it has the potential for highlighting conceptual issues that might otherwise be hard to see.

\section{References}

Adorno, T. (1966). Negative Dialectics. New York: Continuum.

Asimov, I. (1956). I, Robot. New York: Signet.

Asimov, I. (1983). The Robots of Dawn. New York: Doubleday.

Barrat, J. (2013). Our Final Invention: Artificial Intelligence and the End of the Human Era. New York: St Martin's Press.

Beckert, S. (2014). The Empire of Cotton: A Global History. New York: Alfred A. Knopf. 
Boehm, C. (2012). Ancestral hierarchy and conflict. Science, 336, 844-847.

Bolt, J., \& van Zanden, J. L. (2013). The First Update of the Maddison Project: Re-Estimating Growth Before 1820. Groningen: Maddison Project, University of Groningen.

Bowles, S. (2012). Warriors, levelers, and the role of conflict in human social evolution. Science, 336, 876-879.

Bourdieu, P. (2008). The forms of capital. In J. Richardson (Ed.), Handbook of Theory and Research for the Sociology of Education (pp. 280-291). New York: Greenwood.

Boyd, W. (2001). Making meat: Science, Technology, and American Poultry Production. Technology and Culture, 42, 631-664.

Braverman, H. (1974). Labor and Monopoly Capital. New York: Monthly Review Press.

Clutton-Brock, J. (2012). Animals as Domesticates: A World View Through History. East Lansing, MI: Michigan State University Press.

Dietz, T. (2015). Prolegomenon to a structural human ecology of human wellbeing. Sociology of Development, 1(1), 123-148.

Dietz, T., Rosa, E. A., \& York, R. (2009). Environmentally efficient well-being: Rethinking sustainability as the relationship between human well-being and environmental impacts. Human Ecology Review, 16(1), 113-122.

Fitzgerald, A. J., Kalof, L., \& Dietz, T. (2009). Slaughterhouses and increased crime rates: An empirical analysis of the spillover from "The Jungle" into the surrounding community. Organization \& Environment, 22(2), 158-184.

Frey, R G. (2011). Utilitarianism and animals. In T. L. Beauchamp \& R. G. Frey (Eds.), The Oxford Handbook of Animal Ethics, (pp. 172-197). Oxford, UK: Oxford University Press.

Fry, Douglas. (2012). Life without war. Science 336, 879-884.

Grimm, D. (2015). Dawn of the dog. Science, 348(6232), 274-279.

Gunderson, R. (2013). From cattle to capital: Exchange value, animal commodification, and barbarism. Critical Sociology, 39(2), 259-275.

Hart, J. F., \& Mayda, C. (1998). The industrialization of livestock production in the United States. Southeastern Geographer, 38(1), 58-78. 
Hribal, J. (2003). Animals are part of the working class: A challenge to labor history. Labor History, 44(4), 435-453.

Hribal, J. (2007). Animals, agency, and class: Writing the history of animals from below. Human Ecology Review, 14(1), 101-112.

Hribal, J. (2010). Fear of the Animal Planet: The Hidden History of Animal Resistance. Oakland, CA: AK Press.

Hughes, T. P., Carpenter, S., Rockström, J., Scheffer, M., \& Walker, B. (2013). Multiscale regime shifts and planetary boundaries. Trends in Ecology \& Evolution, 28, 389-395.

Ireland, L. J. (2002). Canning canned hunts: Using state and federal legislation to eliminate the unethical practice of canned "hunting". Animal Law, 8, 223-241.

Jerolmak, C. (2013). The Global Pidgeon. Chicago: University of Chicago Press.

Jorgenson, A. K. (2014). Economic development and the carbon intensity of human well-being. Nature Clim. Change, 4(3), 186-189. DOI:10.1038/ nclimate2110.

Jorgenson, A. K., \& Dietz, T. (2015). Economic growth does not reduce the ecological intensity of human well-being. Sustainability Science, 10(1), 149-156. DOI:10.1007/s11625-014-0264-6.

Kalof, L. (2007). Looking at Animals in Human History. London: Reaktion Books.

King, M. B. (2000). Interpreting the consequences of midwestern agricultural industrialization. Journal of Economic Issues, 34(2), 425-434.

Lamb, W. F., Steinberger, J. K., Bows-Larkin, A., Peters, G. P., Roberts, J. T., \& Wood, F. R. (2014). Transitions in pathways of human development and carbon emissions. Environmental Research Letters, 9(1), 014011. DOI:10.1088/1748-9326/9/1/014011.

Latour, B. (2014a). Agency at the time of the Anthropocene. New Literary History, 45(1), 1-18.

Latour, B. (2014b). Another way to compose the common world. HAU: Journal of Ethnographic Theory, 4(1), 301-307.

Lawler, A. (2012a). The battle over violence. Science, 336, 829-830.

Lawler, A. (2012b). Civilization's double-edged sword. Science, 336, 832-833. 
Logan, J. R., \& Molotch, H. L. (1987). Urban Fortunes: The Political Economy of Place. Berkeley, CA: University of California Press.

Longo, S. B., Clausen, R., \& Clark, B. (2015). The Tragedy of the Commodity: Oceans, Fisheries, and Aquaculture. New Brunswick, NJ: Rutgers University Press.

Lough, T. S. (1999). Energy, agriculture, patriarchy and ecocide. Human Ecology Review, 6(2), 100-111.

MacDonald, J. M., \& McBride, W. D. (2009). The transformation of U.S. livestock agriculture: Scale, efficiency, and risks. Washington, DC: U.S. Department of Agriculture.

MacLean, E. L., \& Hare, B. (2015). Dogs hijack the human bonding pathway. Science, 348(6232), 280-281.

Mazur, A., \& Rosa, E. (1974). Energy and life-style: Massive energy consumption may not be necessary to maintain current living standards in America. Science, 186, 607-610.

Mulder, K., Costanza, R., \& Erickson, J. (2005). The contribution of built, human, social and natural capital to quality of life in intentional and unintentional communities. Ecological Economics, 59, 13-23.

Nagasawa, M., Mitsui, S., En, S., Ohtani, N., Ohta, M., Sakuma, Y., Onaka, T., Mogi, K., Kikusui, T. (2015). Oxytocin-gaze positive loop and the coevolution of human-dog bonds. Science, 348(6232), 333-336.

Neumayer, E. (2010). Weak versus Strong Sustainability: Exploring the Limits of Two Opposing Paradigms (3rd ed.). Cheltenham, UK: Edward Elgar.

O'Connor, T. (2013). Animals as Neighbors: The Past and Present of Commensal Animals. East Lansing, MI: Michigan State University Press.

Reid, W. V., Mooney, H. A., Cropper, A., Capistrano, D., Carpenter, S. R., Chopra, K. Dasgupta, P., Dietz, T., Duraiappah, A. K., Hassan, R., Kasperson, R., Leemans, R., May, R. M., McMichael, T. (A. J.), Pingali, P., Samper, C., Sholes, R., Watson, R. T., Zakri, A. H., Shidong, Z., Ash, N. J., Bennett, E., Kumar, P., Lee, M. J., Raudsepp-Hearne, C., Simons, H., Thonell, J.,\& Zurek M. B. (2005). Ecosystems and Human Well-Being: Synthesis. Washington, DC: Island Press.

Schnaiberg, A. (1980). The Environment: From Surplus to Scarcity. New York: Oxford University Press.

Shipman, P. (2015). The Invaders: How Humans and Their Dogs Drove Neanderthals to Extinction. Cambridge, MA: Belknap Press. 
Steinberger, J. K., Roberts, J. T., Peters, G. P., \& Baiocchi, G. (2012). Pathways of human development and carbon emissions embodied in trade. Nature Climate Change, 2, 81-85.

Vemuri, A. W., \& Costanza, R. (2006). The role of human, social, built, and natural capital in explaining life satisfaction at the country level: Toward a National Well-Being Index (NWI). Ecological Economics, 58, 119-133.

World Commission on Environment and Development. (1987). Our Common Future. Oxford, UK: Oxford University Press.

Yang, W., Dietz, T., Kramer, D. B., Chen, X., \& Liu, J. (2013). Going beyond the Millennium Ecosystem Assessment: An index system of human well-being. PloS one, 8(5): e64582.

Yang, Wu, Thomas Dietz, Daniel Boyd Kramer, Zhiyun Ouyang, and Jianguo Liu. (2015). "An integrated approach to understand the linkages between ecosystem services and human well-being." Ecosystem Health and Sustainability 1(5):Article 19. DOI: dx.doi.org/10.1890/EHS15-0001.1.

Yang, W., Dietz, T., Liu, W., Luo, J., \& Liu, J. (2013). Going beyond the Millennium Ecosystem Assessment: An index system of human dependence on ecosystem services. PloS one, 8(5): e64581.

York, R. (2014). Guest editor's introduction: Animal studies and environmental sociology. International Journal of Sociology, 44(1), 3-9.

York, R., \& Longo, S. B. (2015). Animals in the world: A materialist approach to sociological animal studies. Journal of Sociology. DOI:10.1177/1440783315607387.

York, R., \& Mancus, P. (2013). The invisible animal: Anthrozoology and macrosociology. Sociological Theory, 31(1), 75-91. 
This text is taken from Human Ecology Review, Volume 22, Number 1, 2015, published 2015 by ANU Press, The Australian National University, Canberra, Australia. 